\title{
Incorporation of Lead Containing TV Tube Glass Waste in Aluminous Porcelain
}

\author{
Talita Faria Santos ${ }^{a}$,Herval Ramos Paes Junior ${ }^{a, b}$, José Nilson França Holanda ${ }^{a, b *}$ \\ ${ }^{a}$ Post-Graduate Program in Materials Science and Engineering - PPGECM, Universidade Estadual do \\ Norte Fluminense - UENF, 28013-602, Campos dos Goytacazes, RJ, Brazil \\ ${ }^{b}$ Laboratory of Advanced Materials - LAMAV, Universidade Estadual do Norte Fluminense - UENF, \\ 28013-602, Campos dos Goytacazes, RJ, Brazil
}

Received: December 05, 2016; Revised: July 17, 2017; Accepted: August 21, 2017

\begin{abstract}
The aim of this work was to study the incorporation of lead containing TV tube glass waste as a method to provide alternative raw material for aluminous electrical porcelain. For this purpose, aluminous porcelain formulations containing up to $30 \mathrm{wt} . \%$ of TV tube glass waste as a replacement for traditional flux material (sodium feldspar) were pressed and fired in air at $1300{ }^{\circ} \mathrm{C}$ using a fast-firing cycle (<60 min). X-ray diffraction (XRD), scanning electron microscopy (SEM), linear shrinkage, apparent density, water absorption, and electrical resistivity have been carried out. The results indicated that the aluminous porcelain pieces containing up to $30 \mathrm{wt} . \%$ of TV tube glass waste rich in $\mathrm{PbO}$ with water absorption between 0.42 and $0.45 \%$ and volume electrical resistivity between 1.91 and $2.93 \mathrm{x}$ $10^{11} \Omega . c m$ have high potential to work as electrical insulator material. This use of lead containing TV tube glass waste can contribute greatly to reducing the environmental impacts related to it, and also save the sources of non-renewable raw materials used in the electrical porcelain sector.
\end{abstract}

Keywords: TV tube glass, solid waste, aluminous porcelain, properties, microstructure.

\section{Introduction}

Every year huge volumes of solid wastes from electric and electronic equipments (e-waste) are produced in many places around the world, including television sets containing one cathode ray tube $\mathrm{e}^{1-4}$. In the solid waste management field an important issue is the final disposal of the cathode ray tube composed of different glasses, including the lead containing one. In particular, the recycling of lead containing glass is quite problematic. In view of the environmental impacts of the TV tube glass waste pollution, there is a critical need for an ecological and economical solution for the final disposal of this abundant solid waste material.

Aluminous electrical porcelain is a glass-bonded material with excellent technical properties (low water absorption, high electrical resistivity, and high mechanical strength) widely applied to high-tension insulators in electrical power transmission and distribution systems $\mathrm{s}^{5-7}$. The aluminous porcelain formulations consist mainly of a mixture of clay (kaolin and/or plastic clay), fluxing material (feldspars), and filler (alumina) ${ }^{5,8}$. After firing at high temperature, the aluminous porcelain is characterized by a highly dense microstructure composed of mullite and alumina particles embedded in an abundant glassy matrix. Porosity is residual ${ }^{9}$.

In the industrial processing of aluminous porcelain materials an important issue is the cost of the non-renewable pure raw materials ${ }^{7}$. In particular, the aluminous porcelain formulations contain high amount of fluxing materials such as potassium feldspar ( rich in $\mathrm{K}_{2} \mathrm{O}$ ) and sodium feldspar (rich in $\left.\mathrm{Na}_{2} \mathrm{O}\right)^{5}$. On the other hand, the lead bearing TV tube glass waste contains high amount of fluxing oxides ${ }^{2}$. This indicates that the TV tube glass waste could be an attractive option for possible replacement of feldspar material in aluminous porcelain formulation. Previous studies ${ }^{10-14}$ have shown the use of glass waste in the production of traditional ceramic materials. However, the reuse of lead containing TV tube glass waste in aluminous porcelain has not yet been investigated.

The aim of this work was to investigate the incorporation of TV tube glass waste into aluminous porcelain body as partial replacement for sodium feldspar to be used as electrical insulator material.

\section{Materials and Methods}

In this study aluminous porcelain formulations containing up to $30 \mathrm{wt} . \%$ of TV tube glass waste were prepared (Table 1). The standard aluminous porcelain formulation (TF0 formulation) used as a reference consisted of kaolin (20 wt.\%), plastic clay (25 wt.\%), sodium feldspar (35 wt.\%), and alumina $(20 \mathrm{wt} . \%)^{6}$. In the formulations the sodium feldspar was partially replaced with increasing amounts of TV tube glass waste. Commercial kaolin, plastic clay, sodium feldspar, and alumina were used. The TV tube glass waste sample was collected in the Campos dos Goytacazes-RJ region, Brazil. The chemical analysis of the raw materials 
was determined following standard methods: kaolin and sodium feldspar (atomic absorption spectroscopy), alumina (atomic emission spectrophotometry with induction coupled plasma), and plastic clay and TV tube glass waste (X-ray fluorescence spectroscopy).

Table 1. Compositions of the aluminous porcelain formulations (wt.\%).

\begin{tabular}{lcccc}
\hline \multirow{2}{*}{ Raw material } & \multicolumn{4}{c}{ Formulations } \\
& TF0 & TF10 & TF20 & TF30 \\
\hline Kaolin & 20 & 20 & 20 & 20 \\
Plastic clay & 25 & 25 & 25 & 25 \\
Alumina & 20 & 20 & 20 & 20 \\
Sodium feldspar & 35 & 25 & 15 & 5 \\
TV tube glass & 0 & 10 & 20 & 30 \\
\hline
\end{tabular}

The raw materials were dry-ground for $60 \mathrm{~min}$ by using a laboratory ball mill to get the desired fineness $(<45 \mu \mathrm{m})$. All the formulations (Table 1) were mixed, homogenized, and microgranulated via the dry process. Mineralogical analysis was performed by X-ray diffraction (XRD-7000 model, Shimadzu) using $\mathrm{Cu}-\mathrm{K} \alpha$ radiation at a scanning speed of $1.5^{\circ}(2 \theta / \mathrm{min}$. ICDD-JCPDS cards were used to identify the mineral phases. The plastic properties of the porcelain formulations were determined following procedures described in NBR 6459 (1984) and NBR 7180 (1984). The Hausner ratio of the granulated powders was also determined.

The porcelain formulations were moistened with $7 \mathrm{wt} . \%$ water, and pressed in a steel die into disk pieces $(16 \mathrm{~mm}$ in diameter and $10 \mathrm{~mm}$ in height) under uniaxial pressing of $50 \mathrm{MPa}$. After shaping the green pieces were dried at $110^{\circ} \mathrm{C}$ for $24 \mathrm{~h}$, and then fired at $1300^{\circ} \mathrm{C}$ using a fast-firing cycle $(<60 \mathrm{~min}$ ) in a laboratory fast-firing kiln (FSQC-1300/3 model, Maitec).

The following technical properties of the fired pieces have been determined: linear shrinkage, water absorption, apparent density, and electrical resistivity. Linear shrinkage values upon drying and firing were evaluated from variation of the diameter of the disk specimens. Water absorption values were obtained from weight differences between the as-fired and water saturated specimens (immersed in boiling water for $2 \mathrm{~h}$ ). The apparent density was measured by the Archimedes method. The volume electrical resistivity measurements, determined by the method of two points, were performed by using a digital multimeter with $81 / 2$ digits (3458A model, Argilent Technologies), a programmable voltage source (52620G model, Tektromix P), and two conductive plates involving the specimens that were painted with silver conductive ink ${ }^{8}$.

$\mathrm{X}$-ray diffraction analysis was carried out on fired specimens in order to qualitatively evaluate the mineral phases. The microstructure of the fired samples were examined by scanning electron microscopy (SSX-550 model, Shimadzu), at the gold-coated fractured surface.

\section{Results and Discussion}

The mineral phases of the raw materials identified by $\mathrm{X}$-ray diffraction are given in Table 2. As expected, the aluminous porcelain formulations are mainly composed of kaolinite $\left(\mathrm{Al}_{2} \mathrm{O}_{3} \cdot 2 \mathrm{SiO}_{2} \cdot 2 \mathrm{H}_{2} \mathrm{O}\right)$, albite $\left(\mathrm{NaAlSi}_{3} \mathrm{O}_{8}\right)$, alumina $\left(\alpha-\mathrm{Al}_{2} \mathrm{O}_{3}\right)$, quartz $\left(\mathrm{SiO}_{2}\right)$, gibbsite $\left(\mathrm{Al}_{2} \mathrm{O}_{3} \cdot 3 \mathrm{H}_{2} \mathrm{O}\right)$, goethite $\left(\mathrm{Fe}_{2} \mathrm{O}_{3} \cdot \mathrm{H}_{2} \mathrm{O}\right)$, and micaceous mineral. In addition, the partial replacement of sodium feldspar with TV tube glass waste results in the incorporation of amorphous material in the reference formulation. In fact, the X-ray diffraction pattern of the TV tube glass waste sample (Figure 1) presents a typical amorphous band around $2 \theta=27^{\circ}$.

Table 2. Mineral phases identified in the raw materials.

\begin{tabular}{lc}
\hline Raw material & Mineral phases \\
\hline Kaolin & kaolinite and quartz \\
Plastic clay & kaolinite, mica, quartz, gibbsite, and goethite \\
Alumina & $\alpha$-alumina \\
Sodium feldspar & albite and quartz \\
TV tube glass & amorphous phase \\
\hline
\end{tabular}

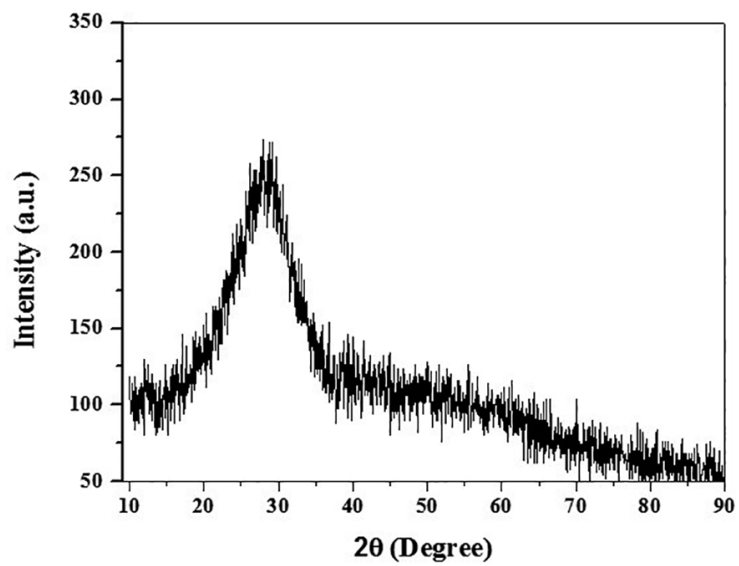

Figure 1. X-ray diffraction pattern of the TV tube glass sample.

Table 3 gives the chemical compositions of the raw materials used in this work. The results indicated the major presence of silicon oxide $\left(\mathrm{SiO}_{2}\right)$, except in the alumina sample. The TV tube glass waste sample contains a significant amount of fluxing oxides, including lead oxide ( $\mathrm{PbO})$. This means that the TV tube glass waste can influence the densification behavior of the aluminous porcelain formulations.

The plastic properties and Hausner ratio of the aluminous porcelain formulations have been presented in Table 4. It is noteworthy that no significant differences are observed in the plasticity index values $(16.0-18.3 \%)$, independently of the added TV tube glass waste amount. It was also found that all aluminous porcelain powders presented a Hausner ratio around unity $(1.016-1.033)$. This indicates that the aluminous porcelain powders produced by the dry process had good flowability characteristics. 
Table 3. Chemical composition of the raw materials (wt.\%).

\begin{tabular}{lccccc}
\hline Oxides & Kaolin & $\begin{array}{c}\text { Plastic } \\
\text { clay }\end{array}$ & Alumina & $\begin{array}{c}\text { Sodium } \\
\text { feldspar }\end{array}$ & $\begin{array}{c}\text { TV tube } \\
\text { glass }\end{array}$ \\
\hline $\mathrm{SiO}_{2}$ & 49.70 & 50.14 & 0.03 & 69.55 & 51.18 \\
$\mathrm{Al}_{2} \mathrm{O}_{3}$ & 33.74 & 26.93 & 97.70 & 18.82 & 1.77 \\
$\mathrm{Fe}_{2} \mathrm{O}_{3}$ & 0.22 & 3.82 & 0.02 & 0.14 & 0.12 \\
$\mathrm{TiO}_{2}$ & 0.01 & 1.41 & - & 0.02 & 0.01 \\
$\mathrm{CaO}$ & 0.30 & 0.37 & - & 0.17 & 2.95 \\
$\mathrm{MgO}$ & 0.06 & - & - & 0.09 & 1.90 \\
$\mathrm{SO}$ & - & 1.70 & - & - & - \\
$\mathrm{K}_{2} \mathrm{O}$ & 1.97 & 0.85 & - & 1.47 & 8.09 \\
$\mathrm{Na}$ & 0.52 & - & 0.12 & 9.63 & 7.69 \\
$\mathrm{PbO}$ & - & - & - & - & 26.29 \\
$\mathrm{LOI}$ & 14.01 & 14.78 & 0.05 & 0.32 & - \\
\hline $\mathrm{LOI}: 10 s$ & 0 & & & &
\end{tabular}

LOI: loss on ignition.

Table 4. Plastic properties and Hausner ratio of the aluminous porcelain powders.

\begin{tabular}{lcccc}
\hline Formulation & UPL (\%) & LPL (\%) & PI (\%) & $\mathrm{Hr}$ \\
\hline TF0 & 35.8 & 19.8 & 16.0 & 1.033 \\
TF10 & 36.1 & 20.1 & 16.0 & 1.033 \\
TF20 & 38.6 & 20.3 & 18.3 & 1.019 \\
TF30 & 38.8 & 21.2 & 17.6 & 1.016 \\
\hline
\end{tabular}

UPL: liquid limit; LPL: plastic limit; IP: plasticity index; Hr: Hausner ratio.

The results of linear shrinkage and bulk density of the aluminous porcelain pieces after drying at $110^{\circ} \mathrm{C}$ are shown in Table 5. It may be observed that only small differences in the drying shrinkage values $(0.20-0.25 \%)$ occurred. The results also showed that the TV tube glass waste containing pieces presented higher bulk density. This effect is related to the high density of the lead containing TV tube glass waste ${ }^{15}$.

Table 5. Physical properties of the porcelain pieces dried at $110^{\circ} \mathrm{C}$.

\begin{tabular}{lcc}
\hline Formulation & $\begin{array}{c}\text { Drying shrinkage } \\
(\%)\end{array}$ & $\begin{array}{c}\text { Bulk density } \\
\left(\mathrm{g} / \mathrm{cm}^{3}\right)\end{array}$ \\
\hline TF0 & 0.20 & 1.67 \\
TF10 & 0.23 & 1.77 \\
TF20 & 0.24 & 1.78 \\
TF30 & 0.25 & 1.79 \\
\hline
\end{tabular}

XRD patterns of the fired pieces at $1300{ }^{\circ} \mathrm{C}$ using a fast-firing cycle for the TF0 and TF30 formulations are shown in Figure 2. For both formulations the following crystalline phases were identified: mullite, quartz, and $\alpha$-alumina. Note that only small differences in the peak intensities occurred. Quartz and $\alpha$-alumina are residual minerals from the starting raw materials. Quartz is due to the plastic clay used. Mullite forms during the firing step from the amorphous metakaolinite ${ }^{16}$. In addition, the partial replacement of sodium feldspar with lead containing glass waste had not significant influence on the phase evolution of aluminous porcelain. However, as shown in Figure $2 b$, the presence of lead containing glass waste tends to promote a higher liquid phase amount, resulting in a larger amorphous band. On the other hand, since no lead oxide peak is observed for the TF30 formulation (Figure $2 \mathrm{~b}$ ), it is plausible to consider that all $\mathrm{PbO}$ (Table 3) has been probably dissolved in the liquid phase on fast-firing process and formed a solid solution.
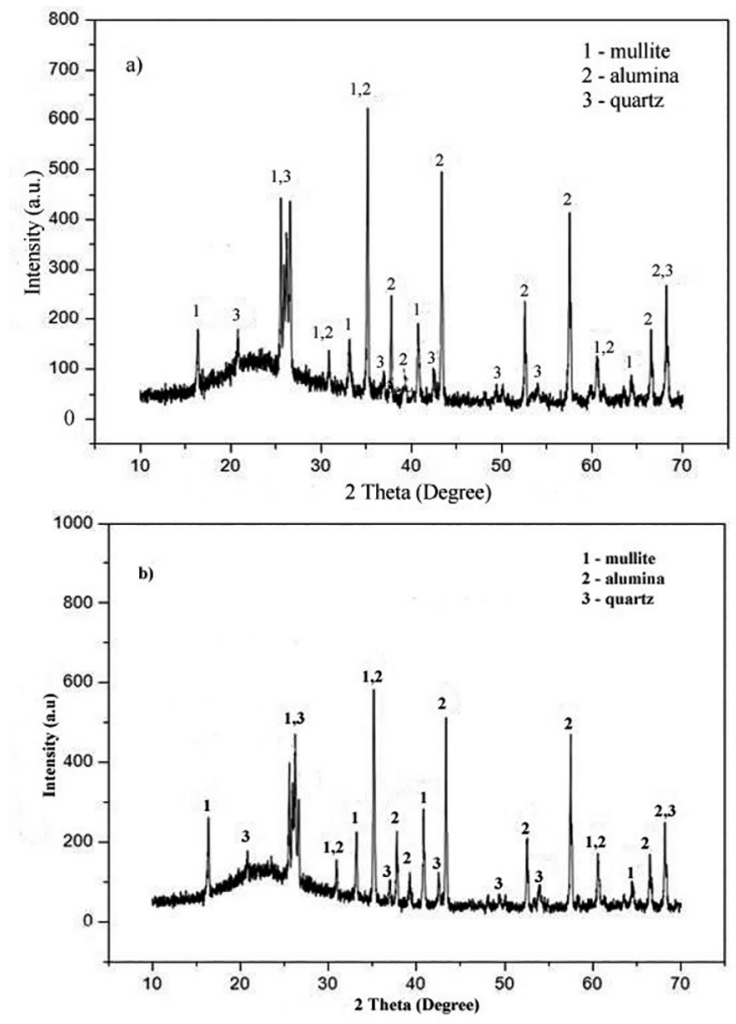

Figure 2. X-ray diffraction patterns of the porcelain pieces fired at $1300{ }^{\circ} \mathrm{C}$ : (a) TF0 formulation; and (b) TF30 formulation.

SEM micrographs of the fracture surfaces of the TF 10 and TF30 formulations fired at $1300^{\circ} \mathrm{C}$ using a fast-firing cycle are shown in Figure 3. It can be seen that the microstructure of the TF10 formulation (Figure 3a) is very homogeneous with a smooth fracture surface, reflecting its high densification degree. According with XRD analysis (Figure 2), it consists of mullite, quartz, $\alpha$-alumina, and glassy phase. However, a more roughened fracture surface with presence of pores for the TF30 formulation (Figure 3b) can be observed. This behavior suggests that the use of TV tube glass waste beyond $30 \mathrm{wt} . \%$ in the aluminous porcelain formulations could result in progressive deterioration of the physical properties.

The densification behavior of the aluminous porcelain pieces has been studied in terms of linear shrinkage, apparent density, water absorption, and electrical resistivity as a function of the added TV tube glass waste amount. 


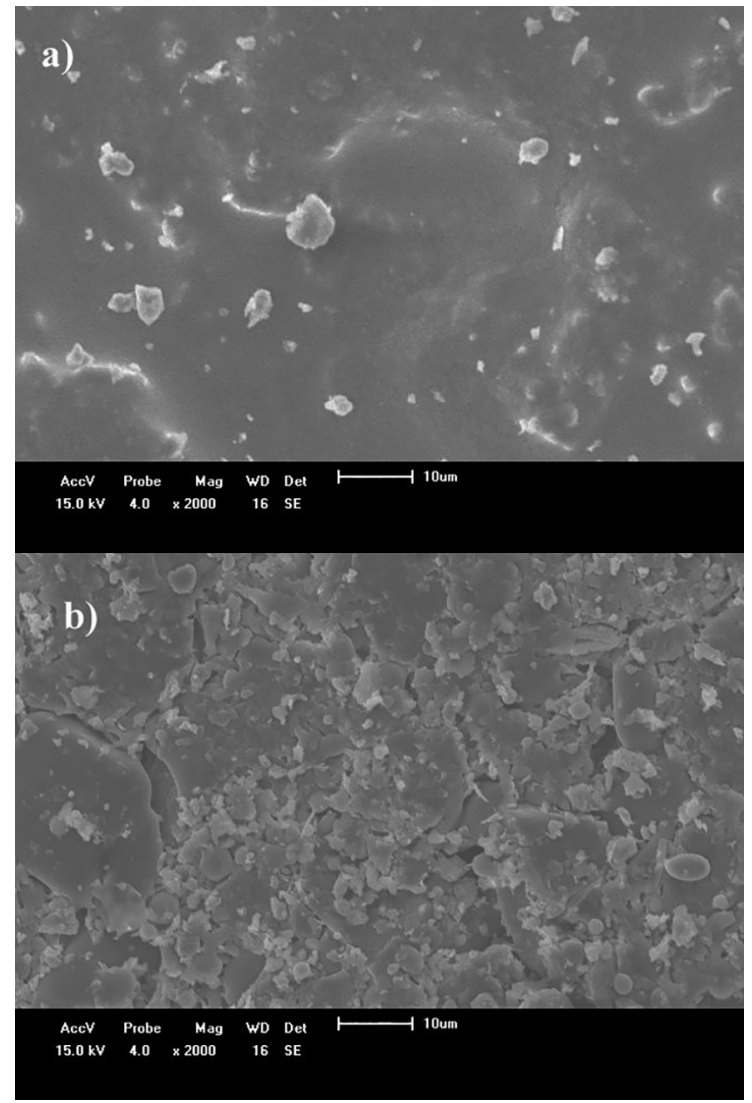

Figure 3. SEM micrographs of the aluminous porcelain pieces fired at $1300{ }^{\circ} \mathrm{C}$ : (a) TF10 formulation; and (b) TF30 formulation.

The linear shrinkage of the fired porcelain pieces is shown in Figure 4. As may be observed, the porcelain pieces presented linear shrinkage values ranging from 9.25 to $10.14 \%$, which are in agreement with the literature ${ }^{17}$. The results also showed that the linear shrinkage presented different behavior with TV tube glass waste addition. It can be seen that the linear shrinkage increased up to $20 \mathrm{wt} . \%$ waste, and then decreased as the TV tube glass waste amount increased. This behavior is probably related to the presence of closed porosity in the aluminous porcelain pieces.

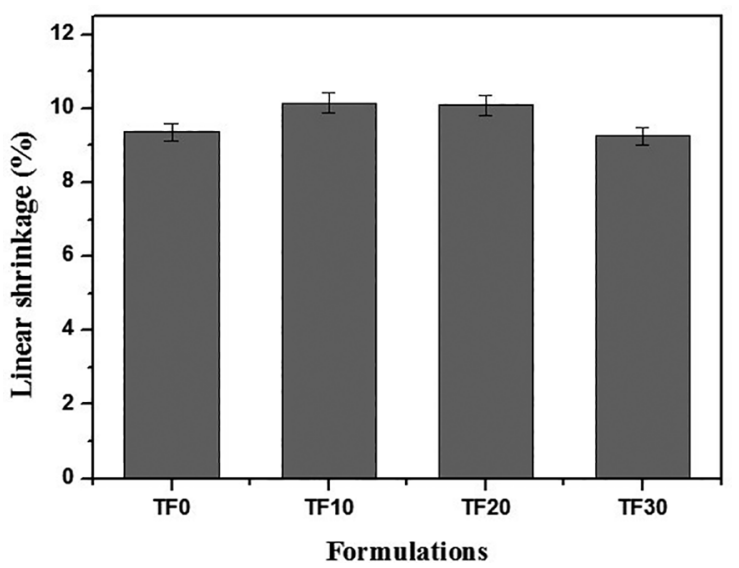

Figure 4. Linear shrinkage of the fired aluminous porcelain pieces.
The apparent density values of the fired pieces are given in Figure 5. The results indicated that all pieces presented apparent density values typical for aluminous porcelain $\left(2.41-2.47 \mathrm{~g} / \mathrm{cm}^{3}\right)$. However, the apparent density presented different behaviors with TV tube glass waste addition. Note that the apparent density values remained practically constant up to $20 \mathrm{wt}$.\% waste addition and then decreased, indicating closed porosity formation with overfiring tendency (structure expansion). This result suggests that the replacement of sodium feldspar with TV tube glass waste in aluminous porcelain formulations is limited. In fact, it has been reported in the literature $^{1}$ that high amounts of glass waste into traditional ceramic formulations should be avoided due to overfiring problems.

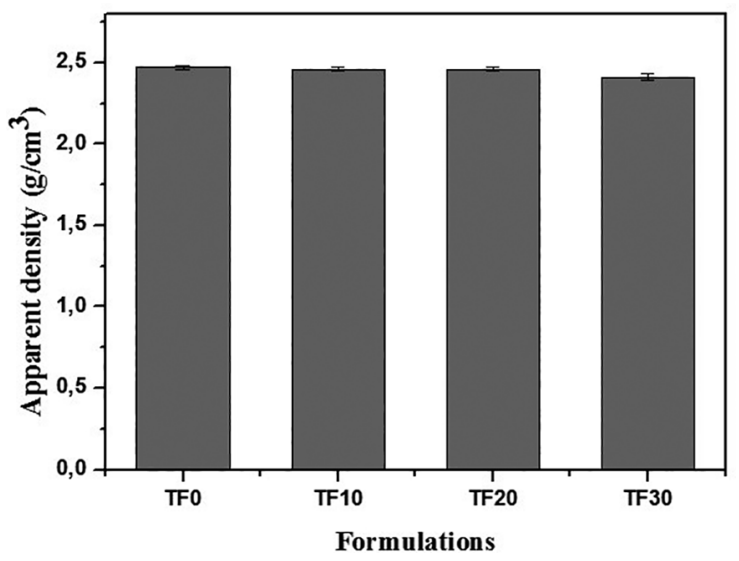

Figure 5. Apparent density of the fired aluminous porcelain pieces.

The water absorption of the fired pieces is shown in Figure 6 . This physical property is essentially related to the sintered microstructure and to the open porosity amount. On the other hand, the electrical porcelain products have strict requirement in terms of water absorption capacity $(<$ $0.50 \%$ ). It can be seen in Figure 6 that all the TV tube glass waste containing pieces achieved the requirement of water absorption $(0.42-0.45 \%)$ for the production of aluminous porcelain. The results also suggest that the partial replacement of sodium feldspar with lead containing glass waste favored the reduction of open porosity of the fired pieces. This behavior enhances the good fluxing characteristic of the lead containing glass waste that tends to cause a decrease on the viscosity of the glassy phase, as confirmed by the lower open porosity.

The volume electrical resistivity of the fired pieces is shown in Figure 7. It can be seen that all the aluminous porcelain pieces fired by using a fast-firing cycle $(<60$ $\mathrm{min})$ presented high electrical resistivity $\left(0.76-2.93 \times 10^{11}\right.$ $\Omega . \mathrm{cm})$. This result indicates that the TV tube glass waste bearing aluminous porcelain pieces could be classified as good electrical insulating material. The electrical resistivity was observed to increase with increasing TV tube glass waste amount. This effect is related to the reduction of 


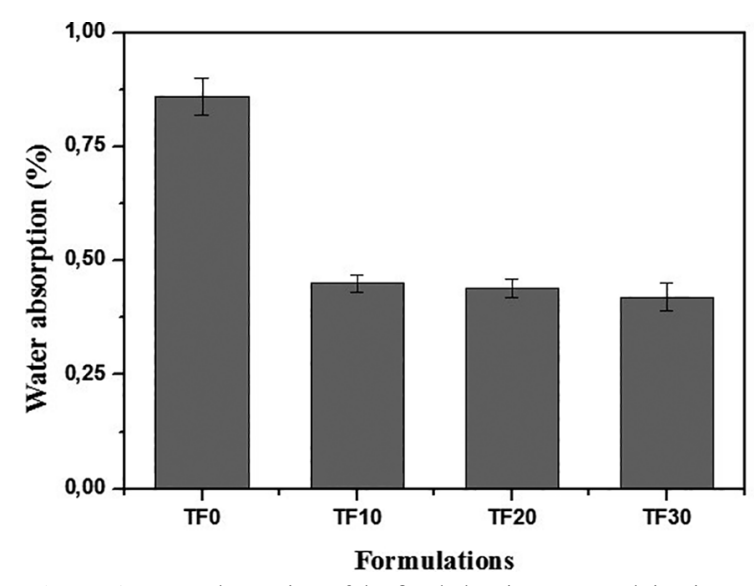

Figure 6. Water absorption of the fired aluminous porcelain pieces.

open porosity as evidenced by the water absorption values (Figure 6), indicating that higher glassy phase amount with lower viscosity was formed. In fact, it has been reported in the literature ${ }^{18}$ that the electrical resistivity of porcelain materials increases with the increase of their glassy phase amount.

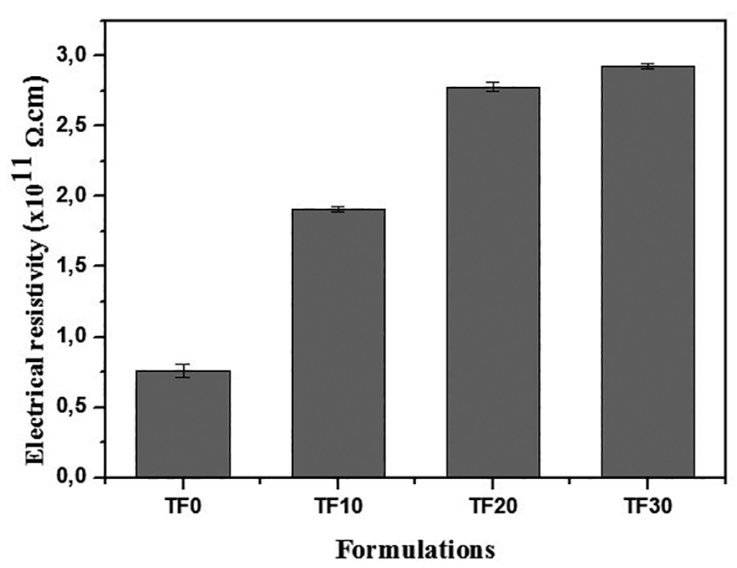

Figure 7. Electrical resistivity of the fired aluminous porcelain pieces.

\section{Conclusions}

The TV tube glass waste is a low-cost, fluxing oxidesrich material $\left(\mathrm{PbO}, \mathrm{K}_{2} \mathrm{O}\right.$, and $\left.\mathrm{Na}_{2} \mathrm{O}\right)$ that could be used as partial replacement to natural flux material (sodium feldspar) in aluminous electrical porcelain formulations. The results of this study suggest that aluminous electrical porcelains containing up to $30 \mathrm{wt} . \%$ of TV tube glass waste produced by using a fast-firing cycle $(<60 \mathrm{~min})$ could serve as high tension porcelain insulators with good technical properties. It was also found that the use of lead containing TV tube glass waste had not obvious effect on the phase evolution of the fired aluminous porcelain formulations. In this context, the valorization of lead bearing TV tube glass waste for aluminous electrical porcelain production is economical, beneficial to society, and environmentally friendly.

\section{Acknowledgements}

The authors acknowledge the CNPq (Process: 305921/20134) and FAPERJ for supporting this work.

\section{References}

1. Andreola F, Barbieri L, Bondioli F, Lancelloti I, Miselli P, Ferrari AM. Recycling of Screen Glass into New Traditional Ceramic Materials. International Journal of Applied Ceramic Technology. 2010;7(6):909-917.

2. Lima NMO, Morais CRS, Lima LMR. Lixo eletrônico: caracterização do vidro do tubo de raios catódicos de computador para reciclagem. Revista Eletrônica de Materiais e Processos. 2011;6(1):59-62.

3. Gong Y, Tian XM, Wu YF, Tan Z, Lv L. Recent development of recycling lead from scrap CRTs: a technological review. Waste Management. 2016;57:176-186.

4. Singh N, Li J, Zeng X. Global responses for recycling waste CRTs in e-waste. Waste Management. 2016;57:187-197.

5. Chinellato AL, Souza DPF. Porcelanas elétricas aluminosas: Parte 1 - Revisão da literatura. Cerâmica. 2004;50(313):62-68.

6. Ramachowski P, Rejmund F, Ramachowski Z, Pawelek A, Piatknowski A. Aluminous porcelain degradation study using mechanoacoustic and microscopic methods. Archives of Electrical Engineering. 2011;60(2):109-128.

7. Piva DH, Piva RH, Venturini J, Ramon J, Caldas V, Morelli $\mathrm{MR}$, et al. Effects of $\mathrm{Fe}_{2} \mathrm{O}_{3}$ content on the electrical resistivity of aluminous porcelain applied to electrical insulators. Ceramics International. 2016;42(4):5045-5052.

8. Silva MA, Paes HR Jr, Holanda JN. Reuse of ornamental rockcutting waste in aluminous porcelain. Journal of Environmental Management. 2011;92(3):936-940.

9. Yqbal Y, Lee WE. Fired Porcelain Microstructure Revisited. Journal of the American Ceramic Society. 1999;82(12):35843590 .

10. Godinho KO, Holanda JNF, Silva AGP. Obtenção e avaliação propriedades tecnológicas de corpos cerâmicos à base de argila e vidros reciclados. Cerâmica. 2005;51(320):420-429.

11. Dondi M, Guarini G, Raimondo M, Camelli C. Recycling $\mathrm{PC}$ and TV waste glass in clay bricks and roof tiles. Waste Management. 2009;29(6):1945-1951.

12. Seo YC, Cho SJ, Lee JS, Kim BS, Oh C. A Study on Recycling of CRT Glass Waste. In: Proceedings of 2011 International Conference on Environment and Industrial Innovation; 2011 Jun 4-5; Kuala Lumpur, Malaysia. IPCBEE. 2011;12:237-241.

13. Oluseyi AK, Atul M, Das SK. Effect of Substitution of SodaLime Scrap Glass for K-Feldspar in Triaxial Porcelain Ceramic Mix. Interceram. 2013;62(4):299-302.

14. Tiffo E, Elimbi A, Manga JD, Tchamba AB. Red ceramics produced from mixtures of kaolinite clay and waste glass. Brazilian Journal of Science and Technology. 2015;2:4. 
15. Méar F, Yot P, Cambon M, Ribes M. The crystallization of waste cathode-ray tube glass. Waste Management. 2006;26(12):1468-1476.

16. Santos PS. Ciência e Tecnologia das Argilas. $2^{\text {nd }}$ ed. São Paulo: Edgard Blücher; 1989.
17. Studard AR, Dias LL, Pandofelli VC, Rodrigues JA, Menegazzo BA, Maurício MRD. Utilização de alumina na fabricação de isoladores elétricos de alta tensão. Cerâmica Industrial. 1996;1:32-36.

18. Chaudhuri SP, Sarkar P, Chakraborty AK. Electrical resistivity of porcelain in relation to constitution. Ceramics International. 1999;25(1):91-99. 